\title{
Does the habitat structure control the distribution and diversity of the Odonatofauna?
}

\author{
Souza, AM. ${ }^{a *}$, Fogaça FNO. ${ }^{a}$, Cunico AM. ${ }^{b}$ and Higuti J. ${ }^{a}$ \\ aPrograma de Pós-Graduação em Ecologia de Ambientes Aquáticos Continentais, \\ Núcleo de Pesquisas em Limnologia, Ictiologia e Aqüicultura, Universidade Estadual de Maringá - UEM, \\ Avenida Colombo, 5790, CEP 87020-900, Maringá, PR, Brazil \\ bUniversidade Federal do Paraná - UFPR, Campus Palotina, Rua Pioneiro, 2153, \\ Jardim Dallas, CEP 85950000, Palotina, PR, Brazil \\ *e-mail: aline_2005_2@hotmail.com
}

Received: October 15, 2013 - Accepted: April 02, 2014 - Distributed: August 31, 2015

(With 3 figures)

\begin{abstract}
The statement that the habitat complexity and structure govern the abundance and diversity of biological communities has been widely investigated. In this context, we assumed the hypothesis of habitat heterogeneity, that is, the higher habitat complexity leads to greater diversity of Odonata. In addition, we analyzed the influence of habitat structure on the distribution of this community, and evaluated the effects of abiotic variables. Odonata larvae were collected with sieves and by electrofishing in ten neotropical streams belonging to the Pirapó River basin. Forty species of Odonata were registered, which were distributed in eight families, Libellulidae stood out with the highest richness. The high gamma diversity and distribution of Odonata were associated with habitat heterogeneity in these streams. However, the abiotic variables also seem to affect the distribution of Odonata species, in view of the impact of the land use in the vicinity of streams.
\end{abstract}

Keywords: insect, habitat heterogeneity, structural complexity, streams.

\section{A estrutura do habitat controla a distribuição e diversidade da Odonatofauna?}

\section{Resumo}

O fato de que a complexidade e estrutura de habitat são reguladores da abundância e diversidade de comunidades biológicas tem sido amplamente investigada. Neste contexto, assumimos a hipótese da heterogeneidade de habitat, ou seja, maior complexidade de habitat conduz a maior diversidade de Odonata. Além disso, foi analisada a influência da estrutura do habitat sobre a distribuição desta comunidade, além de avaliar os efeitos das variáveis abióticas. As larvas de Odonata foram coletadas com peneiras e através da pesca elétrica em dez riachos neotropicais pertencentes à bacia hidrográfica do rio Pirapó. Foram registradas quarenta espécies de Odonata, distribuídas em oito famílias, Libellulidae destacou-se com maior riqueza. A elevada diversidade gama e distribuição de Odonata foram associadas à heterogeneidade de habitat presentes nestes riachos. No entanto, as variáveis abióticas da água parece também ter efeito sobre a distribuição de espécies de Odonata, tendo em vista o impacto do uso do solo dos riachos.

Palavras-chave: insetos, heterogeneidade de habitat, complexidade estrutural, riachos.

\section{Introduction}

The heterogeneity in ecological systems arises from complex interactions that occur in spatial and temporal scales (Stevenson, 1997), influencing patterns of distribution, abundance and diversity and processes of predation, competition, dispersal and habitat selection (Palmer and Poff, 1997). The "habitat heterogeneity hypothesis" assumes that structurally complex environments may provide more niches and forms of exploitation of environmental resources and thus increase species diversity (Tews et al., 2004).

Studies such as by MacArthur and MacArthur (1961), for example, show that for bird species diversity in forests, the physical structure of a plant community of may be more important than plant species composition.

In aquatic environments, habitat complexity plays a key role in the structuring and functioning of aquatic communities (Taniguchi and Tokeshi, 2004; Willis et al., 2005; Tokeshi and Arakaki, 2012). In lotic systems, habitat characteristics vary over short distances, 
thus becoming highly heterogeneous environments, important in maintaining diversity of macroinvertebrates (Tschelaut et al., 2008). Thus, the investigation of the quality of the physical habitat is essential because aquatic fauna often has specific requirements that are independent of water quality (Hannaford et al., 1997).

Several benthic invertebrate species develop various morphological and physiological adaptations strongly associated with habitat conditions and thus can depend on the type, composition and size of the substrate for their distribution in streams (Schröder et al., 2013). The substrate size can vary from larger and more complex, such as pebbles, leaves and woody materials that support a great diversity and abundance, to fine sediments like sand, with few species (Kikuchi and Uieda, 2005). The substrate provides places for food and refuge for benthic invertebrates (Kikuchi and Uieda, 2005). The refuge allows the persistence of invertebrates especially in places disturbed by human activities, besides protection against predation (Magoulick and Kobza, 2003; Brown, 2007).

Odonata larvae are dependent on the habitat characteristics, are sensitive to abiotic variations and have an important role as predator and prey in the trophic structure of aquatic communities (Gómez-Anaya et al., 2011). Water velocity, temperature, disturbance, type of vegetation and substrate are important factors for the distribution of Odonata larvae (Strange et al., 2007). Besides that, the richness and distribution of Odonata can be directly influenced by the variety of habitat structures within a given lotic environment (Dalzochio et al., 2011).

Given the above, the aim of this study was to analyze the influence of habitat structure on the distribution of Odonata over spatial and temporal scales, and to evaluate the effects of abiotic variables. The present study tests the significance of the habitat structure on the Odonatofauna, thus assuming the habitat heterogeneity hypothesis, that is, the habitat complexity leads to higher diversity of Odonata in streams under urban or agricultural influence.

\section{Material and Methods}

\subsection{Study area}

The Pirapó River basin is in the northern Paraná State, on the Third Plateau, specifically in the polygon bounded by latitudes $22^{\circ} 30^{\prime}$ and $23^{\circ} 30^{\prime} \mathrm{S}$ and longitudes $51^{\circ} 15^{\prime}$ and $52^{\circ} 15^{\prime} \mathrm{W}$, with drainage area of approximately $5,076 \mathrm{Km}^{2}$ until its mouth in the Paranapanema River (Sanepar, 2002). In the Pirapó River basin, we selected ten low-order streams $\left(1^{\text {st }}, 2^{\text {nd }}\right.$ and $3^{\text {rd }}$ orders, sensu Strahler, 1957) in the metropolitan region of Maringá (Figure 1) to carry out the collections. According to the percentage of urbanization of the watershed, streams were grouped into urban streams: Nazaré, Mandacarú, Guaiapó, Miosótis and Água do Pirapó (above 50\% of watershed urbanization) and rural streams: Água da Roseira, Água Queçaba, Remo,

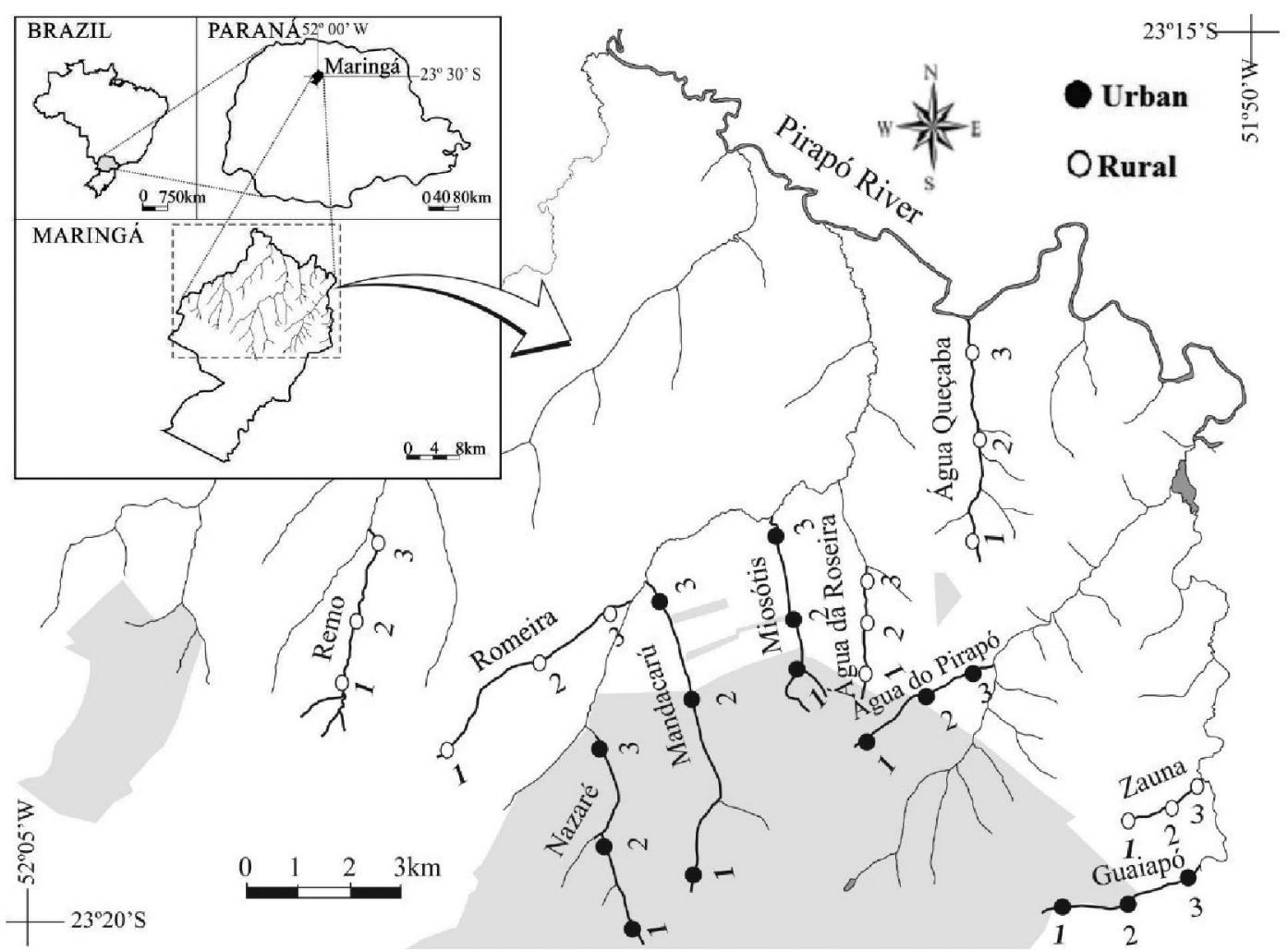

Figure 1. Location and sampling sites (1=Headwaters; $2=$ Middle; $3=$ Mouth $)$ in streams of the Pirapó River basin, Maringá, Paraná State. Grey area represents the urban perimeter of Maringá. 
Zaúna and Romeira (urbanization less than 50\%) (adapted from Cunico et al., 2012). The percentage of urbanization was calculated using the drainage area of each stream by overlaying satellite imagery and altimetry charts (Cunico et al., 2012). The studied streams are continuously altered by human activities, with variation in the major sources of pollutants. The urban streams receive primarily domestic sewage, and rural streams receive effluents mainly from agriculture (Kühl et al., 2010).

\subsection{Collection of Odonata larvae}

Samplings of Odonata larvae were conducted every two months, from July 2007 to June 2008 in ten streams of the Pirapó River basin in three sampling sites (headwaters, middle and mouth) (Figure 1). Odonata larvae were collected with the aid of sieves (mesh opening: $0.5 \mathrm{~mm}$ and $1 \mathrm{~mm}$ ) on various substrates roots, leaf litter, pebbles, gravel, sand and mud. In addition, we used the fish trawls conducted by electrofishing (two dip nets and AC portable generator, $2.5 \mathrm{KW}, 400 \mathrm{~V}, 2 \mathrm{~A}$ ) for sorting Odonata larvae. With the electrofishing equipment were performed three successive captures with constant catch per unit effort (CPUE) in stretches with about 20 times the average width of the river bed ( $40 \mathrm{~m}$ to $80 \mathrm{~m}$ ), thus covering a great amount of habitat types such as riffles, backwaters and pools (Bisson et al., 2006). Larvae were transported alive to the laboratory and kept in screened styrofoam boxes, until the emergence of adults. The exuviae were preserved in $70 \%$ alcohol and the adults were placed in envelopes. The non-emerged larvae were preserved in $70 \%$ alcohol. Individuals were identified to genus and species level, whenever possible. The identification of the larvae was performed according to Santos and Costa (1999) and Costa et al. (2004), and adults according to Heckman $(2006,2008)$.

\subsection{Quantification of habitat structures}

In order to quantify habitat structures we used a wooden square $(0.50 \mathrm{~m} \times 0.50 \mathrm{~m})$ equipped with $10 \mathrm{~cm}$-spaced nylon threads forming a grid with 25 subsections. In each subsection, we identified visually the categories of habitat structures: trunks, branches and leaves, trunks, branches and leaves on the banks, silt, clay, sand, granules, pebbles, blocks, slabs and canopy. The relative frequency of habitat structures was calculated based on the number of subsections in which one category has occurred and based on the total number of subsections sampled. The relative frequencies were used as a measure of the cover of habitat structures, where five replicates were taken at each stretch, and conducted by the same sampler at all sites and samplings, thereby reducing errors of systematic nature (Cunico et al., 2012).

\subsection{Abiotic variables of the water}

Abiotic variables such as electrical conductivity $\left(\mu \mathrm{S} \mathrm{cm}^{-1}\right)$, dissolved oxygen $\left(\mathrm{mg} \mathrm{L}^{-1}\right), \mathrm{pH}$ and temperature $\left({ }^{\circ} \mathrm{C}\right)$ were measured in the field. The analyses of total nitrogen $\left(\mu \mathrm{g} \mathrm{L}^{-1}\right)$, total phosphorus $\left(\mu \mathrm{g} \mathrm{L}^{-1}\right)$, oil and grease $\left(\mathrm{mg} \mathrm{L}^{-1}\right)$, chemical oxygen demand- COD $\left(\mathrm{mg} \mathrm{L}^{-1}\right)$ and biochemical oxygen demand - $\mathrm{BOD}_{5}\left(\mathrm{mg} \mathrm{L}^{-1}\right)$ were analyzed in the
Laboratory of Sanitation and Laboratory of Agrochemistry and Environment of the State University of Maringá.

\subsection{Data analysis}

The rarefaction curve allows the standardization and comparison of the data set, thus rarefaction curves were constructed according to the number of individuals in order to compare species richness between urban and rural streams and between months (Gotelli and Colwell, 2001).

The beta diversity index ( $\beta 2)$ was used to quantify changes in species composition between urban and rural streams and between sampling months. The index was calculated by $\beta 2=\left[\left(\mathrm{R} / \alpha_{\max }\right)-1\right] /[\mathrm{N}-1]$, where $\alpha_{\max }$ is the maximum species richness in $\mathrm{n}$ samples, and $\mathrm{R}$ is the total number of species in the samples (Harrison et al. 1992).

A permutational multivariate analysis of variance (PERMANOVA - Anderson, 2001) was performed on the similarity matrix of habitat structures and the similarity matrix of abiotic variables calculated by Euclidean distance and the similarity matrix of the Odonatofauna calculated by the Bray Curtis distance. This analysis was applied in order to check for significant differences in habitat structures, abiotic variables and Odonatofauna structure between urban and rural streams during the sampling period.

A SIMPER analysis (Clarke, 1993) was run to obtain the relative contribution of abiotic variables that best distinguish urban and rural streams in the months PERMANOVA when was significant.

A BIOENV analysis (Clarke and Ainsworth, 1993) was carried out to test the relationship of the habitat structures and abiotic variables with the Odonatofauna when significant differences were found between urban and rural streams. Between the similarity matrices we calculated the Spearman correlation coefficient, and thus the best subset of habitat structures and abiotic variables was selected and subjected to a permutation test to determine the significance. Owing to the variety of habitat structures and abiotic variables a stepwise model selection was used with the maximum number of six variables, this procedure was repeated 100 times, with a new initial variable being chosen randomly in each round. The model with the highest Spearman correlation and with the lowest number of variables was retained for interpretation.

PERMANOVA, SIMPER and BIOENV analyses, available in the package Vegan, were calculated using the software R 2.15.1 (R Development Core Team, 2011). The calculation of rarefaction curve was performed with the program Biodiversity Pro (Mcaleece et al., 1997).

\section{Results}

\subsection{Odonatofauna diversity}

Table 1 shows the diversity of Odonata species distributed in eight families in the streams of the Pirapó River basin. The gamma diversity was relatively high (40 species), including two likely new taxa. The highest species richness was recorded for Libellulidae, represented by 21 species.

Rarefaction analysis evidenced higher richness in urban streams, but the values in urban ( 28 species) and rural (26 species) were very close. Higher richness were 
Table 1. Diversity of Odonata species in neotropical streams of the Pirapó River basin.

\begin{tabular}{|c|c|c|}
\hline & URBAN & RURAL \\
\hline \multicolumn{3}{|l|}{ ORDER ODONATA } \\
\hline \multicolumn{3}{|l|}{ Suborder Zygoptera } \\
\hline \multicolumn{3}{|l|}{ Family Calopterygidae } \\
\hline Hetaerina sp. 1 & $\mathrm{X}$ & \\
\hline Hetaerina n. sp. & $\mathrm{X}$ & $\mathrm{X}$ \\
\hline \multicolumn{3}{|l|}{ Family Coenagronidae } \\
\hline Acanthagrion ascendens Calvert, 1909 & & $\mathrm{X}$ \\
\hline Oxyagrion sulmatogrossense Costa, Souza \& Santos, 2000 & $\mathrm{X}$ & \\
\hline Oxyagrion sp. 2 & $\mathrm{X}$ & $\mathrm{X}$ \\
\hline \multicolumn{3}{|l|}{ Family Megapodagrionidae } \\
\hline Heteragrion aurantiacum Selys, 1862 & & $\mathrm{X}$ \\
\hline Heteragrion sp. 2 & $\mathrm{X}$ & $\mathrm{X}$ \\
\hline \multicolumn{3}{|l|}{ Family Protoneuridae } \\
\hline Neoneura sp. & $\mathrm{X}$ & \\
\hline Peristicta sp. & $\mathrm{X}$ & \\
\hline \multicolumn{3}{|l|}{ Family Pseudostigmatidae } \\
\hline Mecistogaster $\mathrm{sp}$. & $\mathrm{X}$ & \\
\hline Microstigma sp. & & $\mathrm{X}$ \\
\hline \multicolumn{3}{|l|}{ Suborder Anisoptera } \\
\hline \multicolumn{3}{|l|}{ Family Aeshnidae } \\
\hline Castoraeschna sp. & & $\mathrm{X}$ \\
\hline Neuraeschna sp. & & $\mathrm{X}$ \\
\hline Rhionaeshna planaltica Calvert, 1952 & $\mathrm{X}$ & \\
\hline Rhionaeschna sp. 2 & $\mathrm{X}$ & \\
\hline \multicolumn{3}{|l|}{ Family Gomphidae } \\
\hline Phyllocycla viridipleuris Calvert, 1909 & $\mathrm{X}$ & $\mathrm{X}$ \\
\hline Progomphus complicatus Selys, 1854 & $\mathrm{X}$ & $\mathrm{X}$ \\
\hline Progomphus sp. 2 & $\mathrm{X}$ & $\mathrm{X}$ \\
\hline Tibiogomphus sp. & $\mathrm{X}$ & $\mathrm{X}$ \\
\hline \multicolumn{3}{|l|}{ Family Libellulidae } \\
\hline Brechmorhoga nubecula Rambur, 1842 & $\mathrm{X}$ & $\mathrm{X}$ \\
\hline Brechmorhoga praedatrix Calvert, 1909 & & $\mathrm{X}$ \\
\hline Brechmorhoga sp. 3 & $\mathrm{X}$ & $\mathrm{X}$ \\
\hline Brechmorhoga sp. 4 & $\mathrm{X}$ & $\mathrm{X}$ \\
\hline \multicolumn{3}{|l|}{ Brechmorhoga sp. 5} \\
\hline Brechmorhoga sp. 6 & & $\mathrm{X}$ \\
\hline Brechmorhoga n. sp. & & $\mathrm{X}$ \\
\hline Dythemis sp. & $\mathrm{X}$ & \\
\hline Elasmothemis cannacrioides Calvert, 1906 & $\mathrm{X}$ & $\mathrm{X}$ \\
\hline Elasmothemis sp. 2 & $\mathrm{X}$ & $\mathrm{X}$ \\
\hline Elga sp. & $\mathrm{X}$ & \\
\hline Macrothemis hemichlora Burmeister, 1839 & $\mathrm{X}$ & \\
\hline Macrothemis heteronycha Calvert, 1909 & & $\mathrm{X}$ \\
\hline Macrothemis imitans imitans Karsch, 1890 & $\mathrm{X}$ & \\
\hline Macrothemis sp. 4 & $\mathrm{X}$ & $\mathrm{X}$ \\
\hline Macrothemis sp. 5 & & $\mathrm{X}$ \\
\hline Macrothemis sp. 6 & & $\mathrm{X}$ \\
\hline Macrothemis sp. 7 & $\mathrm{X}$ & \\
\hline Perithemis sp. & $\mathrm{X}$ & $\mathrm{X}$ \\
\hline Planiplax sp. & $\mathrm{X}$ & \\
\hline Tauriphila sp. & & $\mathrm{X}$ \\
\hline
\end{tabular}


observed in September, 20 species. In both cases, there was an increase in the number of species, indicating that the number of sampled individuals does not represent the total richness of Odonata in the streams studied (Figure 2).

Values of beta diversity were low, indicating a homogeneous species composition in urban and rural and in sampling periods. The greatest change in species composition was observed in September and April (Figure 3).

\subsection{Habitat structure}

Streams in urban and rural areas of the Pirapó River basin showed a set of habitat structures (Table 2). In urban streams we found higher percentages of artificial structures $(17 \%)$ and pebbles $(30 \%)$, while in rural streams, higher values were recorded for backwater (56\%), canopy $(95 \%)$ and branches and leaves (32\%). In both groups, predominated silt/clay and sand.

\subsection{Analysis of variance}

PERMANOVA showed a significant difference only in September (Pseudo-F $=5.668, \mathrm{p}=0.0001,9940$ single permutations in 9999) and April (Pseudo-F = $2.6267, \mathrm{p}=0.0218,5471$ single permutations in 9999)

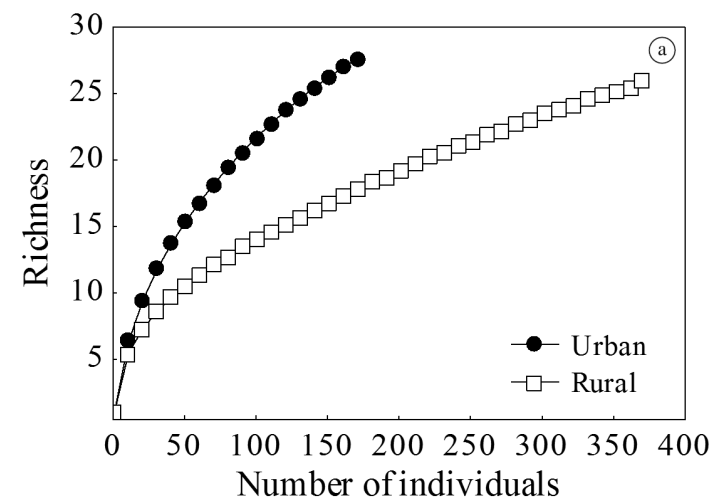

for the abundance and species composition of Odonata. When analyzed the habitat structure and abiotic variables, PERMANOVA pointed out significant differences in all

Table 2. Structural composition of the habitat in neotropical streams of the Pirapó River basin.

\begin{tabular}{lcc}
\hline \multicolumn{1}{c}{ Habitat structures } & Urban (\%) & Rural (\%) \\
\hline Riffles & 28 & 25 \\
Backwaters & 39 & 56 \\
Pools & 33 & 19 \\
Canopy & 64 & 95 \\
Trunks & 0.6 & 1.1 \\
Branches/Leaves & 18 & 32 \\
Trunks/Branches / & 4 & 12 \\
Leaves on the banks & & \\
Artificial structures & 17 & 0.6 \\
Silt/Clay & 77 & 86 \\
Sand & 78 & 90 \\
Granules & 18 & 20 \\
Pebbles & 30 & 26 \\
Blocks & 12 & 7 \\
Slabs & 23 & 13 \\
\hline
\end{tabular}

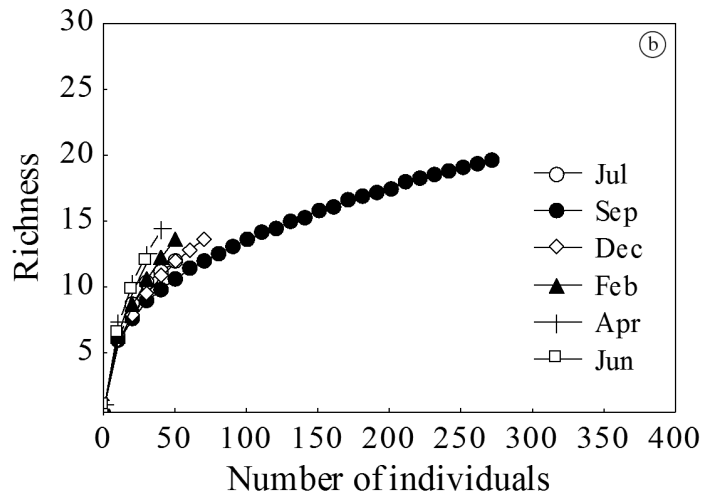

Figure 2. Rarefaction curve of Odonata species in urban and rural streams (a) and in sampling periods (b) (Jul = July, Sep $=$ September, Dec $=$ December, Feb $=$ February, Apr $=$ April, Jun $=$ June) .

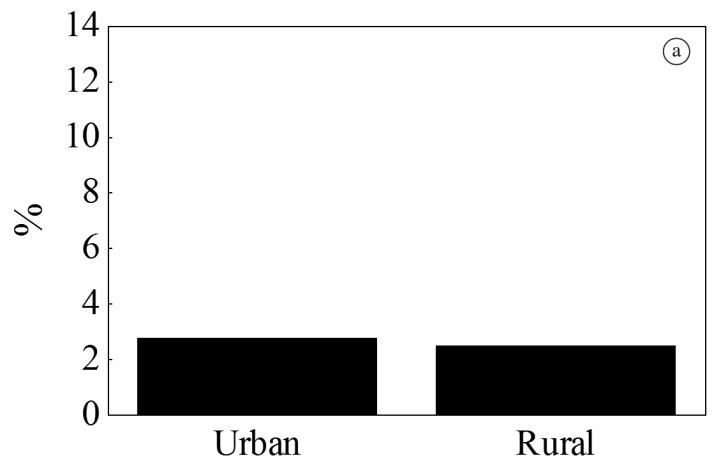

Streams

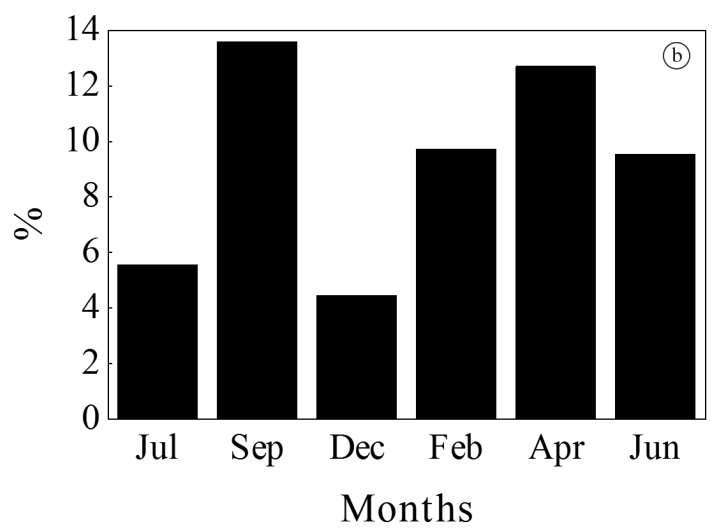

Figure 3. Beta diversity index of Odonata species in urban and rural streams (a) and in sampling periods (b) (Jul = July, Sep $=$ September, Dec $=$ December, Feb $=$ February, Apr $=$ April, Jun $=$ June $)$. 
months, however, are presented data only of September and April, when the Odonatofauna was differentiated between urban and rural streams. The results of the habitat structure were Pseudo-F $=6.913$ and $\mathrm{p}=0.0013$ (9957 single permutations in 9999) in September, and Pseudo-F $=4.5135$ and $\mathrm{p}=0.0091$ (single permutations in 9999) in April. Significant differences of abiotic variables in September and April were Pseudo-F $=3.9718, p=0.0005$ (9921 single permutations in 9999) and Pseudo-F $=4.392$ and $\mathrm{p}=0.0002$ (9921 single permutations in 9999), respectively.

\subsection{Odonatofauna and habitat structure}

BIOENV evidenced a weak association between habitat structures and Odonatofauna, in September and April (Table 3). In September, rho $=0.187$ for canopy, i.e., the canopy alone explains $18.7 \%$ of Odonata distribution. In April, rho $=0.102$ for pebbles and canopy, which explained only $10.2 \%$ of Odonata distribution.

\subsection{Odonatofauna and abiotic variables}

The results of the SIMPER analysis showed a greater relative contribution of total nitrogen and conductivity in the distinction between urban and rural streams in selected months. The cumulative contribution percentages were $59.49 \%$ and $50.09 \%$ in September and April, respectively, indicating the importance of these variables in environmental distinction between rural and urban streams (Table 4).

Although the SIMPER analysis has identified the abiotic variables that best contributed to distinguish rural from urban streams, the results of BioEnv showed no strong relationship between abiotic variables and the Odonatofauna. In September, $\mathrm{pH}$, total phosphorus, total nitrogen and oils and greases explained $22.7 \%$ of the distribution of Odonata, whereas dissolved oxygen and COD explained only $17.7 \%$ in April (Table 5).

Table 3. BIOENV analysis between Odonata community and habitat structures, in September and April.

\begin{tabular}{cccc}
\hline & Selected variables & rho & p-exchanged \\
\hline $\begin{array}{c}\text { September 2007 } \\
\text { Odonata }\end{array}$ & Canopy & 0.187 & $0.04(4999 *)$ \\
$\begin{array}{c}\text { April 2008 } \\
\text { Odonata }\end{array}$ & Pebbles + Canopy & 0.102 & $0.52\left(4999^{*}\right)$ \\
\hline
\end{tabular}

*number of permutations.

Table 4. SIMPER analysis of abiotic variables for rural and urban streams in the Pirapó River basin.

\begin{tabular}{lcccc}
\hline \multicolumn{1}{c}{ September } & $\begin{array}{c}\text { Urban } \\
\text { Mean value }\end{array}$ & $\begin{array}{c}\text { Rural } \\
\text { Mean value }\end{array}$ & Contribution \% & $\begin{array}{c}\text { Accumulated } \\
\text { contribution \% }\end{array}$ \\
\hline Total nitrogen & 3.15 & 0.70 & 13.66 & 13.66 \\
Electrical conductivity & 194.01 & 122.80 & 13.36 & 27.02 \\
Water temperature & 20.87 & 19.81 & 10.96 & 37.98 \\
DQO & 3.00 & 5.38 & 10.92 & 48.90 \\
Oils and greases & 0.84 & 0.49 & 10.59 & 59.49 \\
\hline \multicolumn{1}{c}{ April } & Urban & Rural & Contribution \% & Accumulated \\
& Mean value & Mean value & 16.37 & 16.37 \\
Total nitrogen & 5.48 & 0.95 & 12.46 & 28.83 \\
Electrical conductivity & 202.29 & 139.38 & 10.92 & 39.75 \\
Oils and greases & 1.41 & 0.45 & 10.34 & 50.09 \\
DQO & 1.50 & 2.03 & & \\
\hline
\end{tabular}

Table 5. BIOENV analysis between Odonata community and abiotic variables, in September and April.

\begin{tabular}{lccr}
\hline & Selected variables & rho & p- exchanged \\
\hline $\begin{array}{l}\text { September 2007 } \\
\text { Odonata }\end{array}$ & $\mathrm{pH}$, total phosphorus, total nitrogen and oils and greases & 0.227 & $0.13(4999 *)$ \\
$\begin{array}{l}\text { April 2008 } \\
\text { Odonata }\end{array}$ & Dissolved oxygen and DQO & & \\
\hline *number of & & 0.177 & $0.66(4999 *)$ \\
\hline
\end{tabular}




\section{Discussion}

The high gamma diversity of Odonata in the streams corroborates the hypothesis that greater structural complexity increases the availability of niches, leading to a greater species diversity. According to some authors, the species richness of Odonata depends on the availability and heterogeneity of habitat and many species of Odonata are mainly associated with streams of forested areas (Goertzen and Suhling, 2013; Silva et al., 2010). Thus, this study emphasizes the importance of habitat heterogeneity on the Odonata diversity.

Libellulidae gathers most of Odonata species with wider distribution and richness (Costa et al., 2000; Novelo-Gutiérrez and Gómez-Anaya, 2009), which was also verified in the present study. One characteristic of this family is the largest body size of individuals that increases the dispersal ability (Dalzochio et al. 2011), and thus the species distribution in streams. Further, the dispersal ability of the individuals is indirectly related to the thermoregulatory ability, since both are related to the body size allowing greater flight distances (Juen and De Marco-Júnior., 2011).

Although the richness of Odonata has been relatively high, there is a tendency to increase the richness of Odonata in urban and rural streams, according to the number of individuals captured. However, Odonata species richness is lower with increasing urbanization, indicating that urbanization has a negative effect on the species diversity of Odonata (Willigalla and Fartmann, 2012), since most of their larvae require specific ecological conditions and are very sensitive to environmental changes (Harabiš and Dolný, 2012). Likewise, low values of beta diversity may be related to increasing urbanization and the expansion of agriculture in the vicinity of the streams of the Pirapó River basin. Human activities caused by urbanization and agriculture lead to habitat degradation resulting in the homogenization of species composition (Harabiš and Dolný, 2012).

Research has shown that the type of substrate and the habitat structural complexity are important factors in structuring the macroinvertebrate community, as well as Odonata species (Buss et al., 2004; Silveira et al., 2006). Among the heterogeneity of habitat structures in the streams, the canopy was the structure related to the distribution of Odonata species in early spring (September). The highest vegetation cover in this season coupled with direct influence on the leaf litter biomass in the beds of streams, probably contributed to the presence of Heteragrion aurantiacum e Heteragrion sp. 2 in these streams. This result corroborates Ferreira-Peruquetti and De Marco-Junior (2002), who claimed that Heteragrion species are solely found in streams with riparian vegetation, on leaves and organic sediment, and in places with low current flow. The importance of vegetation cover on the Odonata species distribution was also addressed by Remsburg and Turner (2009), once they provide structures for thermoregulation, foraging, territory defense and protection for adults, and contribute to the input of branches and leaves that provide places for refuge and larval development.

Various studies emphasized the importance of substrate type on the distribution and diversity of Odonata (Carvalho and Nessimian, 1998; Assis et al., 2004). For example, the species of Progomphus live on inorganic substrates and are found burrower in places with predominance of fine sediment, and Brechmorhoga species live in areas of rocky bottom with current (Assis et al., 2004). These characteristics related to the hydrodynamic of environments and distribution of Odonata larvae were also observed in this study. On the other hand, some larvae of Gomphidae and Libellulidae have strategies to avoid predation by fish, burying themselves in the sand (Principe, 2008).

The effect of abiotic variables on the Odonatofauna is probably due to the sensitivity of most species of Odonata (Kalkman et al., 2008). However, little is known about the influence of physical and chemical variables of the water on the distribution of larval Odonata. Nitrogen and phosphorus derived from agricultural waste and organic effluents influenced the Odonatofauna of streams of the Pirapó River basin. According to Moore (1997), pollution from sewage, industrial waste, fertilizers and pesticides decreases the population of Odonata in rivers and streams. Furthermore, some families of Odonata are found in moderately contaminated waters (Hernandez et al. 2012) and thus may be more tolerant to environmental impacts (Buss et al., 2004). In this sense, the structures of the habitat and abiotic variables influenced the Odonatofauna in urban and rural streams of the Pirapó River basin; this influence is due to greater structural complexity found in these streams which showed the greatest diversity of Odonata species. The greater habitat structural complexity was relevant to the diversity and distribution of Odonata in streams under human influence, either by domestic sewage, industrial and/or agricultural effluents. Most larvae of Odonata species are very sensitive to environmental changes and require specific conditions for a successful establishment in a given environment, however, some species possess morphological and physiological adaptations associated with the habitat structure.

\section{Acknowledgements}

To Dr. Yara Moretto (Federal University of Paraná) and the field staff for their assistance in collecting the samples, to Dr. Janira Martins Costa of the Department of Entomology, National Museum, UFRJ (Federal University of Rio de Janeiro) for confirming the identification of genera and species of Odonata. To Jaime Luis Lopes Pereira of NUPÉLIA/UEM (Center for Research in Limnology, Ichthyology and Aquaculture) for drawing up the map. To MCT/CNPq/CT-Hidro (Proc. 555185/2006-0) for funding the project, to PROEX and PEA for financial support, and NUPÉLIA for logistic support. The first author would like to thank CAPES for the scholarship. 


\section{References}

ANDERSON, MJ., 2001. A new method for non-parametric multivariate analysis of variance. Austral Ecology, vol. 26, p. 32-46.

ASSIS, JCF., CARVALHO, AL. and NESSIMIAN, JL., 2004. Composição e preferência por microhábitats de imaturos de Odonata (Insecta) em um trecho de baixada do Rio Ubatiba, Maricá - RJ, Brasil. Revista Brasileira de Entomologia, vol. 48, no. 2, p. 273-282.

BISSON, PA., MONTGOMERY, DR. and BUFFINGTON, JM., 2006. Valley segments, stream reaches, and channel units. In HAUER, FR. and LAMBERTI, GA. (Eds.). Methods in stream ecology. 2nd ed. Burlington: Academic Press. p. 23-49.

BROWN, BL., 2007. Habitat heterogeneity and disturbance influence patterns of community temporal variability in a small temperate stream. Hydrobiologia, vol. 586, p. 93-106.

BUSS, DF., BAPTISTA, DF., NESSIMIAM, JL. and EGLER, M., 2004. Substrate specificity, environmental degradation and disturbance structuring macroinvertebrate assemblages in neotropical streams. Hydrobiologia, vol. 518, p. 179-188.

CARVALHO, AL. and NESSIMIAN, JL., 1998. Odonata do Estado do Rio de Janeiro, Brasil: hábitats e hábitos das larvas. In NESSIMIAN, JL. and CARVALHO, AL. (Eds.). Ecologia de insetos aquáticos. Rio de Janeiro: PPGE-UFRJ. p. 03-28. Series Oecologia Brasiliensis, no. 5.

CLARKE, KR. and AINSWORTH, M., 1993. A method of linking multivariate community structure to environmental variables. Marine Ecology Progress Series, vol. 92, p. 205-219.

CLARKE, KR., 1993. Non-parametric multivariate analyses of changes in community structure. Australian Journal of Ecology, vol. 18 , p. 117-143.

Companhia de Saneamento do Paraná - SANEPAR, 2002. Plano de gestão e manejo do manancial do rio Pirapó, Maringá - PR. Maringá: SANEPAR. 53 p.

COSTA, JM., MACHADO, ABM., LENCIONNI, F. and SANTOS, TC., 2000. Diversidade e distribuição dos Odonata (Insecta) no Estado de São Paulo, Brasil: Parte I: Lista das espécies e registros bibliográficos. Publicaçoes Avulsas do Museu Nacional, vol. 80 , p. $1-27$

COSTA, JM., SOUZA, LOI. and OLDRINI, BB., 2004. Chave para identificação das famílias e gêneros das larvas conhecidas de Odonata do Brasil: comentários e registros bibliográficos (Insecta, Odonata). Publicação Avulsa do Museu Nacional, vol. 99, p. 1-44.

CUNICO, AM., FERREIRA, EA., AGOSTINHO, AA., BEAUMORD, AC. and FERNANDES, R., 2012. The effects of local and regional environmental factors on the structure of fish assemblages in the Pirapó Basin, Southern Brazil. Landscape and Urban Planning, vol. 105, p. 336-344.

DALZOCHIO, MS., COSTA, JM. and UCHÔA, MA., 2011. Diversity of Odonata (Insecta) in lotic systems from Serra da Bodoquena, Mato Grosso do Sul State, Brazil. Revista Brasileira de Entomologia, vol. 55, no. 1, p. 88-94.

FERREIRA-PERUQUETTI, PS. and DE MARCO-JÚNIOR, P., 2002. Efeito da alteração ambiental sobre a comunidade de Odonata em riachos de Mata Atlântica de Minas Gerais, Brasil. Revista Brasileira de Zoologia, vol. 19, no. 2, p. 317-327.
GOERTZEN, D. and SUHLING, F., 2013. Promoting dragonfly diversity in cities: major determinants and implications for urban pond design. Journal of Insect Conservation, vol. 17, p. 399-409.

GÓMEZ-ANAYA, JA., NOVELO-GUTIÉRREZ, R. and CAMPBELL, WB., 2011. Diversity and distribution of Odonata (Insecta) larvae along an altitudinal gradiente in Coalcomán mountains, Michoacán, Mexico. Revista de Biología Tropical, vol. 59 , no. 4 , p. $1559-1577$.

GOTELLI, NJ. and COLWELL, RK., 2001. Quantifying biodiversity: procedures and pitfalls in the measurement and comparison of species richness. Ecology Letters, vol. 4, p. 379-391.

HANNAFORD, MJ., BARBOUR, MT. and RESH, VH., 1997. Training reduces observer variability in visual-based assessments of stream habitat. Journal of the North American Benthological Society, vol. 16, no. 4, p. 853-860.

HARABIŠ, F. and DOLNÝ, A., 2012. Human altered ecosystems: suitable habitats as well as ecological traps for dragonflies (Odonata): the matter of scale. Journal of Insect Conservation, vol. 16, p. 121-130.

HARRISON, S., ROSS, SJ. and LAWTON, JH., 1992. Beta diversity on geographic gradients in britain. Journal of Animal Ecology, vol. 61, no. 1, p. 151-158.

HECKMAN, CW., 2006. Encyclopedia of South American aquatic insects: Odonata - Anisoptera. Dordrecht: Springer. 725 p.

HECKMAN, CW., 2008. Encyclopedia of South American aquatic insects: Odonata-Zygoptera. Dordrecht: Springer. 691 p.

HERNÁNDEZ, YG., MANRIQUE, RR. and CERÓN, AAC., 2012. Guía de campo de los macroinvertebrados acuáticos de la quebrada Menzuly - Santander - Colombia. Bucaramanga: Ediciones Universidad Industrial de Santander. 154 p.

JUEN, L. and DE MARCO-JÚNIOR, P., 2011. Odonate biodiversity in terra-firme forest streamlets in Central Amazonia: on the relative effects of neutral and niche drivers at small geographical extents. Insect Conservation and Diversity, vol. 4, p. 265-274.

KALKMAN, VJ., CLAUSNITZER, V., DIJKSTRA, KDB., ORR, AG., PAULSON, DR. and TOL, JV., 2008. Global diversity of dragonflies (Odonata) in freshwater. Hydrobiologia, vol. 595, p. 351-363.

KIKUCHI, RM. and UIEDA, VS., 2005. Composição e distribuição dos macroinvertebrados em diferentes substratos de fundo de um riacho no município de Itatinga, São Paulo, Brasil. Entomologia y Vectores, vol. 12, no. 2, p. 193-231.

KÜHL, AM., ROCHA, CLMSC., ESPÍNDOLA, ELG. and LANSAC-TÔHA, FA., 2010. Rural and urban streams: anthropogenic influences and impacts on water and sediment quality. International Review of Hydrobiology, vol. 95, no. 3, p. 260-272.

MACARTHUR, RH. and MACARTHUR, JW., 1961. On bird species diversity. Ecology, vol. 42, no. 3, p. 594-598.

MAGOULICK, DD. and KOBZA, RM., 2003. The role of refugia for fishes during drought: a review and synthesis. Freshwater Biology, vol. 48, p. 1186-1198.

MCALEECE, N., LAMBSHEAD, PJD. and PATERSON, GLJ., 1997. Biodiversity pro: free statistics software for ecology. London: The Natural History Museum. Version 2. Available from: <http://gcmd.nasa.gov/records/NHML_Biopro.html>. Access in: 24 Jan. 2012. 
MOORE, NW., 1997. (Compiler). Dragonflies - status survey and conservation action plan. Switzerland: IUCN/SSC/ Odonata Specialist Group. 28 p.

NOVELO-GUTIÉRREZ, R. and GÓMEZ-ANAYA, JA., 2009. A comparative study of Odonata (Insecta) assemblages along an altitudinal gradient in the sierra de Coalcomán Mountains, Michoacán, México. Biodiversity and Conservation, vol. 18, p. 679-698.

PALMER, MA. and POFF, LN., 1997. The influence of environmental heterogeneity on patterns and processes in streams. Journal of the North American Benthological Society, vol. 16, no. 1, p. 169-173.

PRINCIPE, RE., 2008. Taxonomic and size structures of aquatic macroinvertebrate assemblages in different habitats of tropical streams, Costa Rica. Zoological Studies (Taipei, Taiwan), vol. 47 , no. 5 , p. 525-534.

R Development Core Team, 2011. The Comprehensive R Archive Network. Vienna: The R Foundation for Statistical Computing. Version 2.15.1. Available from: <http://www.r-project.org/>. Access in: 10 Apr. 2011.

REMSBURG, AJ. and TURNER, MG., 2009. Aquatic and terrestrial drives of dragonfly (Odonata) assemblages within and among north- temperate lakes. Journal of the North American Benthological Society, vol. 28, no. 1, p. 44-56.

SANTOS, TC. and COSTA, JM., 1999. Description of the last instar larva of Brechmorhoga travassosi Santos and comparison with other Brechmorhoga species (Anisoptera: Libellulidae). Odonatologica, vol. 28, no. 4, p. 425-428.

SCHRÖDER, M., KIESEL, J., SCHATTMANN, A., JÄHNIG, SC., LORENZ, AW., KRAMM, S., KEIZER-VLEK, H., ROLAUFFS, P., GRAF, W., LEITNER, P. and HERING, D., 2013. Substratum associations of benthic invertebrates in lowland and mountain streams. Ecological Indicators, vol. 30, p. 178-189.

SILVA, DP., DE MARCO-JÚNIOR, P. and RESENDE, DC., 2010. Adult odonate abundance and community assemblage measures as indicators of stream ecological integrity: a case study. Ecological Indicators, vol. 10, p. 744-752.
SILVEIRA, MP., BUSS, DF., NESSIMIAN, JL. and BAPTISTA, DF., 2006. Spatial and temporal distribution of benthic macroinvertebrates in a southeastern Brazilian river. Brazilian Journal of Biology, vol. 66, no. 2B, p. 623-632.

STEVENSON, RJ., 1997. Scale-dependent determinants and consequences of benthic algal heterogeneity. Journal of the North American Benthological Society, vol. 16, p. 248-262.

STRAHLER, AN., 1957. Quantitative analysis of watershed geomorphology. Transactions - American Geophysical Union, vol. 38, no. 6, p. 913-920.

STRANGE, AM., GRIFFITHS, GH., HINE, S., YOUNG, K. and HOLLOWAY, GJ., 2007. Habitat associations of the Small Red Damselfly (Ceriagrion tenellum) (De Villiers) in heathland in southern England (Zygoptera: Coenagrionidae). Journal of Insect Conservation, vol. 11, p. 241-249.

TANIGUCHI, H. and TOKESHI, M., 2004. Effects of habitat complexity on benthic assemblages in a variable environment. Freshwater Biology, vol. 49, p. 1164-1178.

TEWS, J., BROSE, U., GRIMM, V., TIELBORGER, K., WICHMANN, MC., SCHWAGER, M. and JELTSCH, F., 2004. Animal species diversity driven by habitat heterogeneity/diversity: the importance of keystone structures. Journal of Biogeography, vol. 31, p. 79-92.

TOKESHI, M. and ARAKAKI, S., 2012. Habitat complexity in aquatic systems: fractals and beyond. Hydrobiologia, vol. 685 , p. $27-47$.

TSCHELAUT, J., WEISSENHOFER, A. and SCHIEMER, F., 2008. Macroinvertebrates and leaf litter decomposition in a neotropical lowland stream, Quebrada Negra, Costa Rica. Stapfia, vol. 88 , p. 457-466.

WILLIGALlA, C. and FARTMANN, T., 2012. Patterns in the diversity of dragonflies (Odonata) in cities across Central Europe. European Journal of Entomology, vol. 109, no. 2, p. 235-245.

WILLIS, SC., WINEMILLER, H. and LOPEZ-FERNANDEZ, H., 2005. Habitat structural complexity and morphological diversity of fish assemblages in a Neotropical floodplain river. Oecologia, vol. 142 , p. 284-295. 